\title{
INTERNAL MARKETING BARRIERS IN EUROPE: PRE-HITLER AUSTRIA AS AN OUTSTANDING EXAMPLE
}

\author{
JACQUES KunsteNAaR*
}

\section{I}

Pre-Hitler Austria is the classic example of a country subjected for years to an economic ideology that became the forerunner of those forces which made her ripe for annexation. In order to understand this development, we have to go back to the year 1848 . The Revolution of 1848 did not substantially affect the economic constitution of Austria, its guild system, which since the Middle Ages had had a strong position in the old Austro-Hungarian Monarchy. On the contrary, growing industrialism, the development of Vienna and Bohemia as centers of European trade and surprising technological progress brought a decline of artisanship which resulted in a tremendous economic and political reaction on the part of the so-called Austrian middle class. That group was never able to grasp the true significance of liberalism, and the formation of large-scale enterprises, such as modern factories, department stores, etc., was considered as an attack of "Judaism and Free Masonry" against the small bourgeoisie. The competitive struggle between declining artisanship, partisan to the past, and the founders of the new economic order became a first-class political issue.

The ideological forefathers of today's National Socialism-Ritter Georg von Schoenerer, the Christian-Social anti-Semitic mayor of Vienna, Karl Lueger, and the Julius Streicher of the nineteenth century, the Christian-Social councilman and master-mechanic, Schneider-knew how to utilize that economic development for their own political ends. This was especially the case with Dr. Lueger, who succeeded in winning over the major part of the small bourgeoisie to the Christian-Social party, which little by little became the center of Austrian reactionaries. The socalled Gewerbeordnung, a body of laws and decrees concerning the plying of a

* A.B., I923, Ph.D., 1932, University of Zurich (Switzerland); London School of Economics; University of Florence; Graduate Institute for International Studies, Geneva. Consulting economist to the Department Stores Association of Switzerland, Associated Cement Industries of Switzerland, etc. Micmber editorial staff of Agence Télégraphique Suisse; economic and financial correspondent Amsterdam daily Algemeen Handelsblad. Associate member of Haworth, Powell \& Thomas, New York City. Author, The Budget of the League of Nations (Zurich, 1932).

The author wishes to acknowledge here the valuable assistance rendered by Mr. Maurice Feldman, formerly economic editor of Der Wiener Tag and member of the economic staff of Stockholm Tidningen, in compiling data for this article. 
handicraft or trade, became more stringent from year to year. The artisans hoped that through the elimination of competition they would obtain a kind of monopoly which would help them to fight successfully the rising industrialists. Every artisan was compelled by law to be a member of his professional corporation or guild. The leaders of these guilds, the Vorsteher, virtually had the power of life and death over members. Their fight against the lower prices of industrial goods was made possible through cutting the costs of hand labor. This they could do because the guilds were entitled to fix the conditions to be complied with in order to become an artisan. For example, any young man who wanted to become a barber had to be an apprentice for four years and a journeyman for many years before he qualified for the master's examination. As a rule, the apprentice did not receive any salary. He had to work I2 to 66 hours a day and his master had the right to beat him. As a matter of fact, he was not treated much better than a slave. After one or two years of apprenticeship, he already did the work of a fully qualified craftsman and therefore the master had, free of charge, a real artisan in his employ. In many cases the number of apprentices was not even limited and thus the masters often had three or four workers whose labor cost them no wages.

The social legislation of the years Igr8-rg2o did away with the major part of these guild prerogatives. The guilds, or corporations, remained, however, and the Gewerbeordnung, though modified, was taken over as to its basic ideas. It cannot be denied that a certain liberal wind started to blow. This was especially true in Vienna under the social-democratic régime which lasted until February, I934. But, when Chancellor Dollfuss took over power in I933 and instituted the partially Fascistic régime in Austria, the old guild spirit re-awoke. From then on, new internal marketing barriers sprang up continually to throttle Austria's economic life.

In the years I934-1938 no enterprise, were it commercial, industrial, or handicraft, could be opened in Austria without the consent of the proper professional corporation. In nine out of ten cases the men who had to make the decisions were direct competitors of the petitioner. If, for example, a seamstress wanted to move her shop to the house across the street, she had to have the consent of the Tailors' Guild and of the competent government office. Not until the competitors had granted her request was she allowed to move. As a rule, and for obvious reasons, requests of this kind were refused.

The same state of affairs existed in regard to factories. According to information from reliable sources, the use of bribery often removed obstacles. Ordinary law making was eliminated and the government ruled by decrees. These decrees of the years 1933 -1938 were based on the emergency measures of 1917. The case of the industrial enterprise Manfred Weiss in Vienna is especially illustrative. This firm established a sewer-pipe factory in Vienna with a capital investment of 5,000,000 schillings. Several hundred workers had found occupation in that factory, a fact of significance inasmuch as at that time there were not less than 800,000 unemployed in Austria. At the occasion of the festive opening of the factory, a representative of 
the Minister of Commerce, Stockinger, welcomed the new undertaking and thanked the management on behalf of the Austrian Government for the newly created employment possibilities. Only one day later, however, the Minister of Commerce decreed that a special license was necessary to operate the pipe factory. This decree had retroactive force. The management of Manfred Weiss applied for a license and was refused. What had happened? Simply that a competitor of Manfred Weiss had used his influence with the Minister!

But not only industry and handicraft suffered internal marketing restrictions; commerce also had to overcome enormous difficulties. At the request of small shopkeepers, the few existing variety stores were ordered to close. If a retailer wanted to open a new shop or add new departments or expand his store, he had to have the consent of the professional organization and of the appropriate government office. Exporters and importers too had to be members of compulsory corporations. The destiny of large enterprises was often in the hands of some petty official. It is said that corruption was the order of the day from 1934 to 1938 and that few ministers were incorruptible.

Price-fixing laws were an integral part of the internal marketing barriers in preHitler Austria. There was practically no economic domain without legal restrictions on the free play of prices. So-called minimum prices were fixed, providing that all goods and services which were affected by these laws could not be sold or rendered below the price fixed by law. As a consequence of these barriers, which practically excluded price competition, consumption diminished and the economic situation of this already impoverished country, with hundreds of thousands of unemployed, became worse and worse. The minimum prices affected mainly those in whose interest they were supposedly established; the small traders and the artisans were the first to suffer from the decline in consumption.

But, the vicious circle was started and there was no way out. The peak was reached when "economic experts" proposed to help the small traders and artisans against their more potent competitors by the introduction of a special tax on machines. In other words, every manufacturer who wanted to add a new machine to his factory would have been obliged to pay a tax. In this way it was hoped to combat efficiency and progress in the interests of a certain class of the population and, willingly or unwillingly, against the interest of the consuming population as a whole. The Council of Ministers studied this taxation plan very thoroughly and examined it in five special sessions. One member of the cabinet actually offered his resignation in case this plan should fail of adoption. It was only the meritorious combined effort of the Austrian Manufacturers Association (Verband der österreichischen Industriellen) and the Exporters Incorporated in the Viennese Merchants Guild (Wiener Kaufmannschaft) which prevented this idiotic plan from being put through.

It is worth while noticing that these same "protectors" of the small traders and artisans did concede monopolies to certain big firms when it suited their political 
aims. Thus the whole steel industry, at both the production and merchandising stages, was in the hands of or at least dependent upon, the German Alpine Montan Gesellschaft. This enterprise advanced large sums to finance the Austrian Fascist guard, the Heimwehr. It had a great influence on the governments of Dollfuss and Schussnigg. The company was so strong that it secured protective tariffs even for qualities of steel which it did not itself produce. Interviewed at a press conference about the catastrophic consequences of this protective tariff policy, a director of the Alpine Montan Gesellschaft cynically invited rival artisans and manufacturers either to adapt themselves to the qualities which the company was willing to produce, or to quit business.

Internal marketing barriers were also to be found in Austrian agriculture. An illustrative example: farmers received 18 groschen for a liter of milk, whereas the consumer had to pay 49 to 52 groschen for it. A kilogram of butter cost the consumer 4 schillings to 5 schillings 50 , whereas the farmer received only I schilling 60 for it. Austrian butter, however, was exported to England at the price of I schilling ro a kilogram. The difference between I schilling ro and I schilling 60 was paid to the farmer out of public funds. For every liter of milk, 3 groschen had to be paid by the consumer into a so-called Milk Compensation Fund (Milchausgleichskasse).

The butter price was so high in Austria that butter became prohibitive for the majority of consumers. The public turned more and more to the cheaper margarine. The government retorted by taxing the manufacturers of margarine to such an extent that margarine nearly reached the price of butter. The consumption of margarine therefore dropped too although the consumption of butter did not increase, because people simply could not afford to buy it. As a consequence of this economic policy the production of margarine had to be restricted and the number of unemployed was again augmented.

We find the same disastrous effects caused by internal marketing barriers and especially by price-fixing in other agricultural fields, particularly in the sugar and wine industries. The fixing of minimum prices caused consumption to decrease; the farmers, in whose interest price-fixing was decreed, were drawn deeper and deeper into the crisis.

Thus under the half-Fascistic régimes of Dollfuss and Schussnigg internal barriers became a source of personal aggrandizement to a few political leaders, while unemployment rose from day to day. Farmers, manufacturers and merchants became more and more involved in debt. Import duties were raised but tax revenues dropped. The consumption of practically all foodstuffs and articles of daily use decreased sharply. A sense of bitterness took hold of large parts of the population. Workers and employees, former Social-Democrats, were already opposed to the Austrian form of Fascism. The so-called middle class and some of the farmers who first had sympathized with the Dollfus and Schussnigg régimes for their reactionary economic philosophy in opposition to economic progress and efficiency, began to set their hopes on German National Socialism. 
There can be no doubt as to the reciprocal action of internal marketing barriers and the political happenings in Austria. Indeed, there is probably no country in Europe in which economic legislation and, especially, internal marketing barriers had such an influence on national political development as in Austria. It is not impossible that without the events of February, I934, and without the exhumation of the old Austrian guild constitution at that time, Austria might today still be an independent country.

\section{II}

Illustrative of the absurd lengths to which the Austrian internal marketing barriers were carried was the federal law establishing arbitration courts for price-cutting cases, decreed by the government on October 26, I934 (Bundesgesetz über die Errichtung von Schiedsstellen für Preisschleudereisachen). This Austrian law was a very careful attempt to solve the problem of price-cutting. For its execution arbitration courts were formed consisting of one professional judge as president and two members of the trade or profession involved in the case as associate judges. The jurisdiction of these courts covered, so far as price-cutting was concerned, offenses against the Austrian law of unfair competitive practices which by paragraph I declares:

Whosoever in business engages in unfair competitive practices can be restrained from continuing the offensive procedure and can be held liable in damages therefor. ${ }^{1}$

The law became effective on the first of November, 1934, with a provisory validity until the 3rst of December, I935. The short period of validity was to enable the law-makers to obtain some experience which would place them in a position to work out a law modified by experience or to prolong the life of the original enactment. But the effects of the law proved so disastrous that it had to be repealed when it expired at the end of 1935 .

Though the Austrian press was censored and could not give free vent to the true feelings of the economic circles involved, it is nevertheless possible to cite some newspaper articles which are characteristic of the objections created by this law. The semi-official Reichspost, commenting in No. 259 of the igth of September, 1935, on a lecture delivered by Dr. Wilhelm Loebell, a high government official, wrote:

The decisions of the arbitration courts are contradictory. The same facts are declared legal in one case and illegal in another and this leads to considerable insecurity. This is not meant as a criticism of the arbitration courts, which were created without being afforded guidance as to what price-cutting really means. The artisans, who form an important part of our corporative order, have, in the last few years, forcefully demanded that offenders commirting price-cutting be legally liable. The law-makers did their best to meet that wish and studies were made by competent organizations to define price-

\footnotetext{
I "Wer im geschäftlichen Verkehr zu Zwecken des Wettbewerbes Handlungen vornimmt, die gegen die guten Sitten verstossen, kann auf Unterlassung und Schadenersatz in Anspruch genommen werden." In the pages following free translation is given to German language sources.
} 
cutting. It must, however, be said that the organizations approached were not in a position to define the meaning of price-cutting.

Even members of the Austrian Chamber of Artisans (Oesterreichische Gewerbebund) developed a critical attitude toward the legal possibilities of combating price-cutting. Dr. Ernst Stadler, executive secretary of the Association of Austrian Artisans, declared in No. 276 of the Reichspost of the 6th of October, 1935:

The decisions of the arbitration courts have been disappointing in many cases, as they were to a high degree contradictory and unstable. This is not due to the fault of the arbitration courts, but to the fact that there is no definition of what price-cutting really means.

The former Austrian Chancellor, Ernst Streeruwitz, one of the most ardent proponents of a law against price-cutting and who was, to a great extent, responsible for its enactment, had, during the year 1935, much cause for comment on the experiences with this temporary law. In No. 278 of the Reichspost of the 8th of October, I935, Streeruwitz said:

It cannot be denied that a certain uniformity in the decisions of the arbitration courts must be demanded. It must be recognized, however, that in view of the tremendous number of cases and the short time during which the law was enforced, it was not easy to regulate satisfactorily the intervention in the mechanism of prices.

A law system which does not guarantee uniformity in the application of justice must be denounced as a sheer legalization of arbitrary methods.

The application of the law produced, as a further consequence, a sizable increase in consumer prices. On the I4th of March, 1935, the prominent Austrian newspaper Neue Freie Presse published the following letter to the editor:

A few days ago my wife wanted to buy a pat of margarine, for which she used to pay 68 groschen. The grocer told her, however, that though he regretted it, he had now to get 88 groschen for the same amount of fat. He had been perfectly satisfied with a profit of $20 \%$, but he had been denounced as an offender against the price-cutting laws and was now obliged to take a profit of $42 \%$ !

In the Reichspost dated July 6th, I935, we read as follows:

A grocer was denounced by members of his guild because he had sold salad oil below the decreed retail prices. To that he objected that he was making a profit of $13 \%$ as he was able to buy at favorable prices and conditions. He urged, moreover, that his overhead charges were very low, as he conducted the business with the sole help of his wife. His average income amounted to about 500 schillings a month. He stated furthermore that salad oil of a similar quality was being sold in the market at the same price. In the decision of the arbitration court, these points were not questioned. It was, however, concluded that the merchant had sold under the retail prices decreed by his guild. His sales had therefore to be considered as an unfair competitive practice. The majority of his colleagues had been adhering to the fixed prices. The earnings in individual cases were considered by the law courts as absolutely irrelevant. 
An editorial of the Reichspost of the 6th of July, 1936 , is equally illustrative.

Within the last few months we were compelled several times to criticize certain factors contributing to the fixation of price in Austria. Even if the tendency toward rising prices is based on the decisions of the arbitration courts, this status is unbearable. Just now, even if we ignore our external competitive needs as to export, tourism, etc., the fact remains that what is necessary is higher market turnovers and not higher prices. We could not hope for such an increase if prices had a tendency to rise, while the income remained the same. We must not allow such a price formation which results in a diminution of the volume of trade, even if this tendency is based on juridically correct decisions of the arbitration courts. It is not feasible to force the arbitration courts to fix prices for goods or services.

On the $3^{\text {rd }}$ of January, 1936, that is, three days after the law in question became inoperative, the semi-official Reichspost commented editorially as follows:

The Reichspost has many times had cause to show by drastic examples the weaknesses of the law, which in a number of cases proved to be nonsensical. Not infrequently did it harm the serious merchant satisfied with a fair profit, but who, by reason of his efficiency, could sell cheaper than his competitor who cited him before the court of arbitration.

On the 6th of March, 1936, Minister Baar-Baarfels delivered a lecture before the Niederösterreichischer Gewerbeverein in which he definitely shattered the hope of those who still believed in a revival of the court of arbitration in price-cutting cases. The experiences gained had convinced even partisans of this economic philosophy that it was, in the end, a shortsighted policy. Baar-Baarfels said:

I want to state forcefully that the Government is not inclined to interfere with the mechanism of prices by fixing them authoritatively or by passing similar measures. It is the Government's aim to create a condition which would warrant a fair income to production and to the small and large trade. Excess profits would only result in a superfluous increase in prices which would be felt by the consumer. We are by no means advocating a competition free of any and all barriers, but we are not willing by forceful intervention to eliminate the economic laws concerning the price mechanism.

The decisions of the courts of arbitration show conclusively that it is impossible to define the meaning of price-cutting in an objective manner and that such an attempt to settle complicated economic processes by law was bound to fail. In point because it illustrates to what absurd lengths these kinds of laws can be abused is decision Ps 6/35-5 of the gth of March, 1935. There an innkeeper was sued by his competitors because he had sold half a broiler with potato salad at the price of only $\mathrm{I}$ schilling. In a lengthy dissertation, the court analyzed the case and decided finally that no offense against the law was committed.

In decision Ps $8 / 35-4$ of the I4th of March, 1935, the defendant was found guilty. because he had sold a tube of dental cream at I schilling 20 instead of the fixed price of I schilling $4^{0}$. In the opinion of the court it is stated that a buyer sent by a competitive firm went into the store and positively begged the merchant to sell her the dental cream at the lower price. The merchant finally, though reluctantly, 
agreed; whereupon he was denounced by his competitors. In decision Ps $62 / 35^{-8}$ of the 24th of May, I935, a house painter was found guilty of unfair competitive practices because he had undertaken a painting job at a lower price than was usual among his competitors for this kind of work. He was restrained from continuing the offensive procedure and held liable in damages therefor in spite of the fact that his profits amounted to 439 schillings 76 on a bill of only 1,313 schillings $73 !$ In decision Ps $39 / 35-7$ of the $25^{\text {th }}$ of April, I935, a grocer was found guilty of pricecutting because he had been able to pass on to the consumer the advantages of his efficient buying and organization. In spite of the fair income of 600 schillings monthly which he was able to make while charging lower prices, he was condemned because he had sold at a cheaper price than did the majority of his trade. This was considered by the arbitration court to be an unfair competitive practice.

The foregoing are just a few illustrative examples, which could be multiplied indefinitely, of the pernicious effect on Austrian business and consumers of one of the most back-breaking and economically unjustifiable of internal marketing barriers.

\section{Bibliography for Further Reading}

Bayer, Prof. Dr. Hans, Text und Kommentar, Die Oesterreichische Gewerbeordnung (Oesterreichische Kammer für Arbeiter \& Angestellte, Wien, 1937).

Dobretsberger, Prof. Dr. Josef, Die Wirtschaftspolitischen Aufgaben des Neuen Staates (Oesterreichischer Verlag für Kunst und Wissenschaft, I937); also Der Kampf Gegen das Monopol (Vortrag gehalten im Juli 1937).

Feldman, Maurice, Moderne Maschinenstürmer (Der Wiener Tag, Nov. 3, I937).

Stoiber, Dr. Jacob (Generalsekretär der Hauptkörperschaft österr. Landwirtschaftskammern), Probleme der Oesterreichischen Landwirtschaft (Im Verlag Agrarische Verlagstelle, I929).

Wolff, Reinhold P., Foreign Experience With Retail Price Controls (1940) 5 J. MaRkeTING I43.

Arbeiterzeitung (Organ der Sozialdemokratischen Partei Oesterreichs, I93I, I932 and 1933).

Der Handel (Offieilles Organ des Gremiums der Wiener Kaufmannschaft, 1936 and I937).

Der Handel und Gewerbetreibende (Offizielles Organ des Verbandes Sozialdemokratischer Handel- und Gewerbetreibender, Juni r932).

Die Industrie (Offizielles Organ des Hauptverbandes der österreichischen Industrie, Mai, Juni und Juli r937).

Die Gewerbeordnung des Bundesstaates Oesterreichs und Ihre Novellierungen (Oesterreichischer Bundesverlag, I937).

Veröffentzichungen des Bundesamtes fur Statistik und der Industriellen BezirkskoMmission (März I929 bis Januar 1938).

Kammer fuer Handel, Gewerbe und Industrie, Bericht des GewerbefoerderungsINstrrutes, I936 (Verlag der Oesterreichischen Kammern für Handel, Gewerbe und Industrie).

Neue Freie Presse (Wien) rgo6-1912, I918-1936. 